\title{
Chemical Pleurodesis for Malignant Pleural Effusion: How Far Have We Come in 80 Years?
}

\author{
Coenraad F.N. Koegelenberg Morné J. Vorster \\ Division of Pulmonology, Department of Medicine, Stellenbosch University and Tygerberg Academic Hospital, \\ Cape Town, South Africa
}

Malignant pleural effusion (MPE) is one of the most common causes of pleural exudates worldwide. Approximately $30-50 \%$ of all patients with metastatic malignancies will have pleural involvement at autopsy, and half of these will have pleural effusions, ranging from insignificant to massive [1].

Patients with a symptomatic MPE and an expected median survival of more than 3 months should be offered definitive palliative intervention, which may include chemical pleurodesis and/or the insertion of an indwelling pleural catheter (IPC). Globally, there is major heterogeneity in the therapeutic approach to MPE, mostly because of the paucity of high-quality evidence [2].

Chemical pleurodesis is achieved by the instillation of a sclerosant via a small-bore chest tube, IPC or during thoracoscopy. Amazingly, the most commonly used agent, talc, was first introduced as far back as 1935 [3]. In the largest randomised study on MPE of over 450 patients, the success rate of talc pleurodesis was approximately $75 \%$ at 1 month, but it was progressively reduced to approximately $50 \%$ at 6 months [4]. The same study found that talc poudrage was not superior to talk slurry, except in cases with lung and breast cancer [4].

Respiratory failure and acute respiratory distress syndrome (ARDS) have been associated with talc pleurode- sis, most likely because of the systemic absorption of small-size talc particles [2]. In a multicentre, open-label, prospective cohort study of 558 patients with MPE who underwent thoracoscopy and talc poudrage with $4 \mathrm{~g}$ of calibrated French large-particle talc, no patients developed ARDS, although oxygenation deteriorated in the first few days after talc pleurodesis [5].

Other agents that have been used for chemical pleurodesis over the years include bleomycin, tetracycline and doxycycline. A meta-analysis of 10 randomised studies found that non-recurrence of effusion was more likely with talc than other sclerosants, suggesting that there is little advantage of using other agents over largeparticle talc [6]. Only doxycycline has success and complication rates comparable to talc [7].

The search for the most effective and safe agent for chemical pleurodesis is ongoing. Many reports shave suggested that iodopovidone (povidone-iodine) may be as effective as talc, with a comparable complication rate, although others have suggested that its use may be associated with serious complications including renal failure, confusion, visual loss and even neonatal hyperthyroidism [8]. Neto et al. [9] previously reported a retrospective analysis of 61 pleurodesis procedures with iodopovidone performed in 54 patients. They observed a very high suc-

\section{KARGER 125}

(c) 2015 S. Karger AG, Base

0025-7931/15/0905-0355\$39.50/0 
cess rate of $98.4 \%$, with a paucity of complications, and suggested that the agent may be a good option for chemical pleurodesis [9].

In this issue of Respiration, Andrade Neto et al. [10] describe the safety profile of iodopovidone when used as a sclerosant to achieve pleurodesis in MPE. A total of 60 patients with MPE, who were not allergic to iodine, had a good performance status and had total or near total lung expansion after pleural drainage were enrolled in their prospective study. Patients were randomised to pleurodesis with either 1 or $2 \%$ iodopovidone. The overall failure rate was very low, which was also not unexpected given the inclusion criteria and the fact that the majority of patients had metastatic breast cancer. A total number of 47 serious events were reported in 34 of the 60 patients, implying that more than half of all patients experienced at least one serious adverse event. Pleuritic pain was common, as expected, but of concern was the frequency of metabolic disturbances, including hyponatremia and deranged liver enzymes. Subclinical hypothyroidism was observed in 5 patients. No differences were observed between the groups randomised to either 1 or $2 \%$ iodopovidone with regard to adverse events, efficacy and quality of life.

The same group recently reported the safety profile of three different doses of silver nitrate used for pleurodesis in MPE [11]. Once again, adverse events raised concerns. Serious events included acute kidney injury, ARDS and confusion. Four patients died during this study, with one death possibly related to the agent [11].

The Brazilian team of investigators should be commended for seeking effective and safe alternatives to talc pleurodesis, albeit that their recent studies suggest that neither iodopovidone nor silver nitrate will soon replace large-particle talc as the agent of choice for chemical pleurodesis.

Clearly, little progress has been made over the past eight decades in finding the ideal sclerosant for chemical pleurodesis, and in an era of high-quality evidence-based medicine, the management of MPE is still largely based on expert opinion rather that high-quality data.

Studies comparing chemical pleurodesis with IPC have yielded conflicting evidence with regard to efficacy, quality of life and cost-effectiveness [2]. Current interest focuses around combining IPC with pleurodesis, either spontaneous or chemical [2]. Ultimately, the answer probably lies in an individualised approach rather than any one specific modality, as many factors, including patient preferences, tumour type, prognosis, performance status, recurrence rate of the effusion and involvement of the underlying lung, impact on the success of any intervention offered.

\section{References}

1 Heffner J, Klein J: Recent advances in the diagnosis and management of malignant pleural effusions. Mayo Clin Proc 2008;83:235.

2 Azzopardi M, Porcel MJM, Koegelenberg CFN, Sa FCP, Lee YCG, Fysh ETH: Current controversies in the management of malignant pleural effusions. Semin Respir Crit Care Med 2014;35:723-731.

3 Bethune N: Pleural poudrage: new technique for the deliberate production of pleural adhesion as preliminary to lobectomy. J Thorac Surg 1935;4:251-261.

4 Dresler C, Olak J, Herndon J 2nd, et al: Phase III intergroup study of talc poudrage vs talc slurry sclerosis for malignant pleural effusion. Chest 2005;127:909-915.
Janssen J, Collier G, Astoul P, et al: Safety of pleurodesis with talc poudrage in malignant pleural effusion: a prospective cohort study. Lancet 2007;369:1535-1539.

6 Shaw P, Agarwal R: Pleurodesis for malignant pleural effusions. Cochrane Database Syst Rev 2004;1:CD002916.

7 Porcel J, Salud A, Nabal M, Vives M, Esquerda A, Rodríguez-Panadero F: Rapid pleurodesis with doxycycline through a small-bore catheter for the treatment of metastatic malignant effusions. Support Care Cancer 2006; 14:475478.

8 Agarwal R, Paul A, Aggarwal A, Gupta D, Jindal S: A randomized controlled trial of the efficacy of cosmetic talc compared with iodopovidone for chemical pleurodesis. Respirology 2011;16:1064-1069.
9 Neto J, de Oliveira S, Vianna S, Terra R: Efficacy and safety of iodopovidone pleurodesis in malignant pleural effusions. Respirology 2010;15:115-118.

10 Andrade Neto JD, Terra RM, Teixeira RM, Pereira SV, Pego-Fernandes PM: Safety profile of the use of iodopovidone for pleurodesis in patients with malignant pleural effusion. Respiration 2015;90:369-375.

11 Terra RM, Bellato RT, Teixeira LR, Chate RC, Pego-Fernandes PM: Safety and systemic consequences of pleurodesis with three different doses of silver nitrate in patients with malignant pleural effusion. Respiration 2015;89: 276-283. 